\title{
Urban rail transport and SARS-CoV-2 infections: an ecological study in Lisbon Metropolitan Area
}

Milton Severo ${ }^{1,2^{*}}$, Ana Isabel Ribeiro ${ }^{1}$, Raquel Lucas ${ }^{1,2}$, Teresa Leão ${ }^{1,2}$ \& Henrique Barros $^{1,2}$

1-EPIUnit - Instituto de Saúde Pública, Universidade do Porto, Rua das Taipas, no 135, 4050-600 Porto, Portugal.

2-Departamento de Ciências da Saúde Pública e Forenses e Educação Médica, Faculdade de Medicina, Universidade do Porto, Porto, Portugal.

${ }^{*}$ Corresponding author

Milton Severo

EPIUnit - Instituto de Saúde Pública, Universidade do Porto, Rua das Taipas, no 135, 4050-600 Porto, Portugal

Tel: +351222061820

Fax: +351222061821

e-mail:milton@med.up.pt

\section{AUTHORSHIP CONTRIBUTION STATEMENT}

Milton Severo: Conceptualization, Statistical analysis, Interpretation of the results, Writing - review \& editing.

Ana Isabel Ribeiro: Geographical data processing, Interpretation of the results, Writing - original.

Raquel Lucas: Interpretation of the results, Writing - review \& editing.

Teresa Leão: Interpretation of the results, Writing - review \& editing.

Henrique Barros: Conceptualization, Supervision, Interpretation of the results, Writing review \& editing.

\section{ACKNOWLEDGMENTS}

The authors are grateful to Direção-Geral da Saúde for providing the data from the National Epidemiological Surveillance System (SINAVE). 


\section{FUNDING}

This study was funded by FEDER through the Operational Programme Competitiveness and Internationalization and national funding from the Foundation for Science and Technology - FCT (Portuguese Ministry of Science, Technology and Higher Education) under the Unidade de Investigação em Epidemiologia - Instituto de Saúde Pública da Universidade do Porto (EPIUnit) (UIDB/04750/2020). Ana Isabel Ribeiro was supported by National Funds through FCT, under the programme of 'Stimulus of Scientific Employment - Individual Support' within the contract CEECIND/02386/2018. 


\section{Urban rail transport and SARS-CoV-2 infections: an ecological study in Lisbon Metropolitan Area}

\section{ABSTRACT}

Introduction: Large number of passengers, limited space and shared surfaces can transform public transportation into a hub of epidemic spread. This study was conducted to investigate whether proximity to railway stations, a proxy for utilization, was associated with higher rates of SARS-CoV-2 infection across small-areas of Lisbon Metropolitan Area (Portugal).

Methods: The number of SARS-CoV-2 confirmed infections from March 2 until July 5, 2020 at parish-level was obtained from the National Epidemiological Surveillance System. We used a Geographic Information System to estimate proximity to railway stations from the six railway lines operating in the area. Then, we fitted a quasi-Poisson generalized linear regression model to estimate the relative risks (RR) and corresponding 95\% Confidence Intervals $(95 \% \mathrm{Cl})$.

Results: Between May 2 and July 5, 2020, there were a total of 17,168 SARS-CoV-2 infections in the Lisbon Metropolitan Area, with wide disparities between parishes.

Globally, parishes near one of the railway lines (Sintra) presented significantly higher SARS-CoV-2 infection rates ( $R R=1.42,95 \% \mathrm{Cl} 1.16,1.75)$ compared to those parishes located far away from railway stations, while the opposite happened for parishes near other railway lines (Sado/Fertagus), whose infection rates were significantly lower than those observed in parishes located far away from railway stations $(\mathrm{RR}=0.66,95 \% \mathrm{Cl}$ $0.50,0.87)$. However, the associations varied according to the stage of the epidemic and according to mitigation measures in place. Regression results also revealed an increasing influence of socioeconomic deprivation on SARS-CoV-2 infections.

Conclusions: We found no consistent association between proximity to railway stations and SARS-CoV-2 infection rates in the most affected metropolitan area of the country, suggesting that other factors (e.g. socioeconomic deprivation) might play a more prominent role in the epidemic dynamics.

Key-words: SARS-CoV-2; Transport policy; Disease transmission; coronavirus; urban health. 
medRxiv preprint doi: https://doi.org/10.1101/2020.09.18.20195776; this version posted September 18, 2020. The copyright holder for this

\section{INTRODUCTION}

By the beginning of 2020, societies worldwide were experiencing an unprecedented, disruptive event - the coronavirus disease 2019 (COVID-19) pandemic caused by the severe acute respiratory syndrome coronavirus 2 (SARS-CoV-2). The first confirmed case of COVID-19 in Europe was identified on January 23, 2020, and in Portugal the first case was diagnosed on March 2, 2020 (1). According to the latest data available (from September 14, 2020), there were a total of 65,021 confirmed cases of COVID-19 and 1875 deaths in Portugal.

Urban areas have been epicentres of the COVID-19 pandemic (2). In Portugal, reported SARS-CoV-2 infections are concentrated in the two main metropolitan areas of the country: Lisbon Metropolitan Area and Porto Metropolitan Area, which account for $46 \%$ and $23 \%$ of all reported infections, respectively, while concentrating $28 \%$ and $17 \%$ of the population in the country. Many who live, work, and attend school in urban areas use public transportation (metro, bus, trains) for daily commuting. Public transportation can act as a hub for epidemic spread, since there is a high number of individuals in close proximity in closed spaces, making it difficult to keep a safe distance (3). The existence of multiple surfaces, such as seats, handrails, doors, and ticket machines, shared daily by thousands of individuals, also facilitate the transfer of SARS-CoV-2 virus (4), which is believed to persist in surfaces for several hours (5). Notably, public transport is more used by low-income individuals, who do not have the possibility to opt for other modes of transportation such as a personal car (6). Adding to this, recent studies suggest that low-income individuals are more likely to be affected by most of the known risk factors for COVID-19, such as poor housing conditions, presence of comorbidities and occupation in essential sectors, such as industry, cleaning, food supply or construction (7-9).

During the lockdown period, the role of public transportation on epidemic spread was not considered particularly relevant as most countries recorded a drastic reduction in the use of public transportation (10). In Portugal, the State of Emergency was declared on March 19, 2020 and was renewed biweekly until May 2, 2020 (11). State of Emergency legislative measures enforced the closure of international borders and the suspension of non-essential services and events. Residents could leave their homes only to shop for basic needs, to take care of vulnerable people, to walk their dogs or dispose of daily residuals, and to go to work. Travelling to work was limited to those in essential jobs, and working from home was encouraged as the norm. Consequently, between March and May 2020, we observed a remarkable decrease of 70 to $80 \%$ in the utilization of public transportation (10). 
As the lockdown eased and workplaces and services reopened, the use of public transport grew again, although as of September 2020, it still remained below the prelockdown levels (12). Lisbon Metropolitan Area is the most populated metropolitan area of the country and concentrates the highest proportion of residents that use public transport on a daily basis, namely urban trains. According to the latest Population and Housing Census (2011), 7.6\% of the population from Lisbon Metropolitan Area uses trains as their main mode of transportation versus $2.9 \%$ in the whole country (13).

Coincidentally, after the lockdown eased, from June onwards, Lisbon Metropolitan Area recorded the largest growth in the number of SARS-CoV-2 infections and in July three quarters of all daily cases were reported in residents of that area. Lay media and other stakeholders started to question whether the upsurge in SARS-CoV-2 infections in the metropolitan area could be related with the large number of passengers that use Lisbon Urban railway services on a daily basis to commute.

A study conducted in China looked at the factors influencing the number of imported cases from Wuhan and the spread speed and pattern of the pandemic, and found that the presence of an airport or high-speed railway station was associated to the speed of the infection spread, although its link with the number of confirmed cases was weak (14). Another study, also focused on Wuhan, reported a strong association between travel by train to six major Chinese cities and the number of SARS-CoV-2 cases (15). Yet, these studies did not evaluate the role of urban short-duration train trips, typically used for daily commuting, on the number of SARS-CoV-2 infections. In addition, little is known on the role of public transport on transmission following the application of widespread containment or mitigation measures.

This ecological study was conducted to investigate whether proximity to urban railway stations, a proxy for utilization in daily commuting, was associated with higher rates of SARS-CoV-2 infection across small-areas from Lisbon Metropolitan Area, between March and July 2020. 


\section{Materials and Methods}

\subsection{Study design}

This ecological study used Lisbon Metropolitan Area parishes (smallest administrative territorial unit) as observation units and compared the SARS-CoV-2 infection rates between the parishes closer and parishes farther from a train station, operationally defined below, while taking into account the specific train line that runs through the closest station.

\subsection{Study area}

The Lisbon Metropolitan Area NUT III (Nomenclature of Territorial Units for Statistics III) lies on the centre-south region of Portugal and includes 18 municipalities and 118 parishes. It is the most populated metropolitan area of the country and, according to the latest population estimates (31 December 2018), holds 2.86 million inhabitants. It should be noted that, although the geographical overlap is not complete, the Lisbon Metropolitan Area holds $78 \%$ of the population from the Lisbon Health Administration Region (Administração Regional de Saúde de Lisboa e Vale do Tejo, ARSLVT), to which reported infection cases are assigned.

\subsection{SARS-CoV-2 infections}

We used data on the cumulative number of SARS-CoV-2 infections in Lisbon Metropolitan Area, according to the parish of occurrence, from March 2 until July 5, 2020. Data was obtained from National Epidemiological Surveillance System (SINAVE) and provided by Directorate-General of Health (Direção-Geral da Saúde, DGS). SINAVE is a real-time electronic platform used by public, private and social healthcare institutions in Portugal to collect data on communicable diseases and other public health risks (16). The information collected is based on international standards for disease surveillance, recommended by the European Centre for Disease and Control and by the World Health Organization, and reported on the electronic form provided by SINAVE on https://sinave.min-saude.pt (16). After the submission of the notification by an authorized user, the data is made available in real-time for the local, regional and national health authority. The data is validated consecutively, by hierarchical level, to assure the validity of the reported information and to avoid duplicate cases. 
medRxiv preprint doi: https://doi.org/10.1101/2020.09.18.20195776; this version posted September 18, 2020. The copyright holder for this preprint (which was not certified by peer review) is the author/funder, who has granted medRxiv a license to display the preprint in perpetuity.

All rights reserved. No reuse allowed without permission.

\subsection{Train station network and geospatial procedures}

The list of railway stations in the Lisbon Metropolitan Area and corresponding railway lines was obtained on the websites from CP - Comboios de Portugal (https://www.cp.pt/passageiros/pt) and Fertagus (https://www.fertagus.pt/).

When this study was conducted (7 July 2020), there were a total of six railway lines operating in the study area. Four belonged to Comboios Urbanos de Lisboa (Linha de Azambuja, Linha do Sado, Linha de Sintra and Linha de Cascais) and two lines belonged to Comboios Regionais/Suburbanos (Linha do Oeste and Linha do SulFertagus), including a total of 71 railway stations depicted in Figure 1.

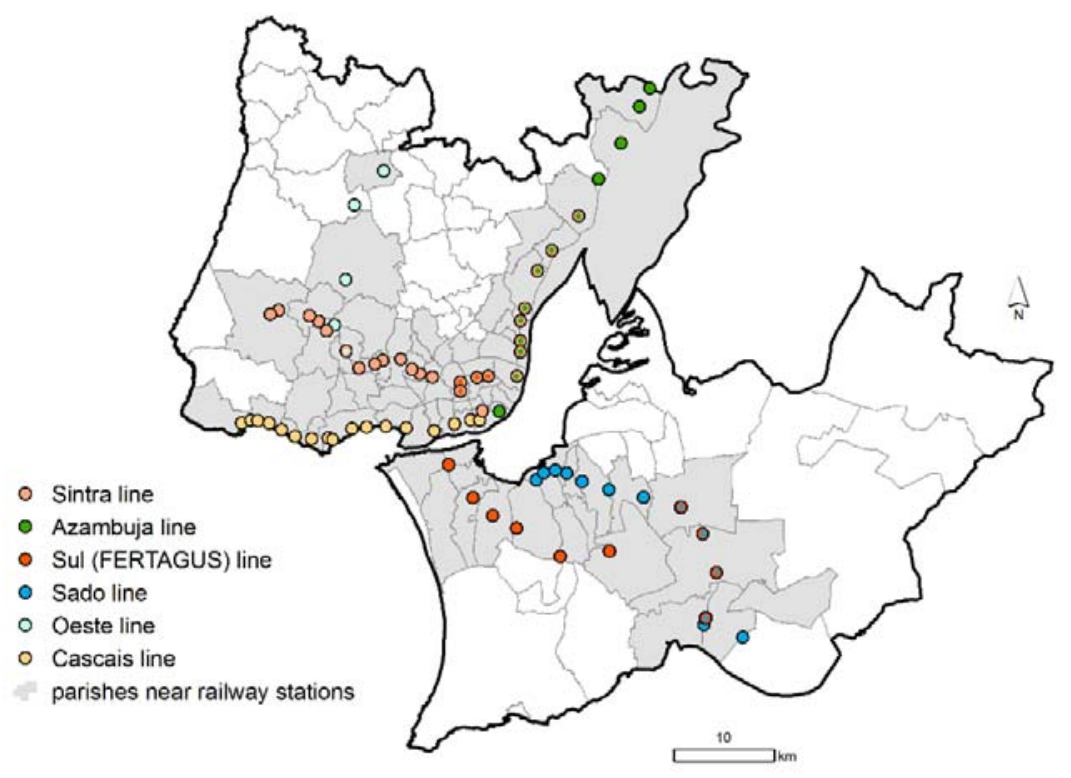

Figure 1. Location of the railway stations from Lisbon Metropolitan Area in 5 July 2020.

Using the official administrative cartography as a base map (Carta Administrativa Oficial de Portugal version 2019, CAOP 2019 (17)) and a Geographic Information System (ArcGIS 10.7.1), we created a 100×100 meter grid covering all the parishes belonging to Lisbon Metropolitan Area. Afterwards, using the centroid of each grid cell as origin, we computed the Euclidian distance (i.e. straight line) from that centroid to the nearest railway station. With the resultant distance matrix, we computed the shortest distance from each parish to the nearest railway station. Because each parish can be close to various stations, served by different railway lines, we assigned each parish to the line that ran through the nearest station. Then, we grouped the parishes into: parishes near railway stations (those at a mean minimum distance equal or shorter than 3000 meters, $n=76$ ) and parishes farther from railway stations (those at a 
medRxiv preprint doi: https://doi.org/10.1101/2020.09.18.20195776; this version posted September 18, 2020. The copyright holder for this preprint (which was not certified by peer review) is the author/funder, who has granted medRxiv a license to display the preprint in perpetuity.

All rights reserved. No reuse allowed without permission.

mean minimum distance larger than 3000 meters, $n=42$ ). The parishes classified as near railway stations are depicted in gray color in Figure 1.

\subsection{Statistical analysis}

To estimate the magnitude of the association between SARS-CoV-2 infection rates and proximity to railway station at the parish-level (closer vs. farther), we fitted a quasiPoisson generalized linear regression model with the log of the population as offset to estimate the relative risks (RR) and corresponding 95\% Confidence Intervals $(95 \% \mathrm{Cl})$. To control for confounding, models were adjusted for socioeconomic deprivation assessed by the European Deprivation Index (EDI). The EDI was constructed in three steps, fully described elsewhere (18), and resulted from the weighted sum of the following standardized variables at parish-level: percentage of non-owned households; households without indoor flushing; households with five rooms or less; individuals with blue-collar (manual) occupations; individuals with low education level ( $\leq 6$ th grade); non-employers; unemployed looking for a job; and foreign residents.

The analysis was stratified according to four periods each representing a stage in the epidemic spread and mitigation measures: March-July (the whole analysis period 02/03 to $05 / 07$ ), March (the early stage of the epidemic and transition to State of Emergency, 02/03 to 31/03), April (State of Emergency, 1/04 to 30/04), May (end of the State of Emergency and beginning of State of Alert, 01/05 to 31/05) and June-July (State of Alert, $01 / 06$ to $05 / 07)$. Statistical analysis was performed using $R$ software version 4.0.0.

\section{RESULTS}

Between March 2 and July 5, 2020 there was a total of 17,168 SARS-CoV-2 infections in the Lisbon Metropolitan Area: 1272 in March, 3257 in April, 4566 in May and 8073 in June/July. Infection rates across the Lisbon Metropolitan Area varied substantially ranging from 26 cases per 100,000 inhabitants in Santo Isidoro (Mafra) to 1725 cases per 100,000 in Alvalade (Lisbon), in the whole period.

Table 1 presents the relative risks comparing infection rates in the parishes near railway stations, according to railway line, with those from parishes located far away. Globally, parishes near the Sintra railway line presented significantly higher SARSCoV-2 infection rates (RR $1.4295 \% \mathrm{Cl} 1.16,1.75)$ compared to those parishes located far away from railway stations, while the opposite happened for parishes near the Sado/Fertagus lines, whose infection rates were significantly lower than those 
medRxiv preprint doi: https://doi.org/10.1101/2020.09.18.20195776; this version posted September 18, 2020. The copyright holder for this preprint (which was not certified by peer review) is the author/funder, who has granted medRxiv a license to display the preprint in perpetuity.

All rights reserved. No reuse allowed without permission.

observed in parishes located farther away from railway stations $(\mathrm{RR} 0.6695 \% \mathrm{Cl} 0.50$ 0.87). However, this pattern changed through the course of the epidemic and according to the measures in place at each time.

Table 1. Associations (Relative Risk, RR, and 95\% Confidence Intervals, 95\%Cl) between railway station proximity and COVID-19 infection rates.

\begin{tabular}{|c|c|c|c|c|c|}
\hline & March-July & March & April & May & June-July \\
\hline $\begin{array}{l}\text { Parishes far away from } \\
\text { railway stations }\end{array}$ & $\operatorname{Ref}(1.00)$ & $\operatorname{Ref}(1.00)$ & $\operatorname{Ref}(1.00)$ & $\operatorname{Ref}(1.00)$ & $\operatorname{Ref}(1.00)$ \\
\hline $\begin{array}{l}\text { Parishes near railway } \\
\text { stations from Azambuja } \\
\text { line }\end{array}$ & $\begin{array}{l}1.15(0.90 \\
1.49)\end{array}$ & $\begin{array}{l}1.26(0.77 \\
2.04)\end{array}$ & $\begin{array}{l}1.11(0.74 \\
1.65)\end{array}$ & $\begin{array}{c}1.19(0.86 \\
1.65)\end{array}$ & $\begin{array}{c}1.06(0.80 \\
1.40)\end{array}$ \\
\hline $\begin{array}{l}\text { Parishes near railway } \\
\text { stations from Cascais line }\end{array}$ & $\begin{array}{l}0.99(0.75 \\
1.29)\end{array}$ & $\begin{array}{l}1.60(1.03 \\
2.51)\end{array}$ & $\begin{array}{c}1.14(0.76 \\
1.69)\end{array}$ & $\begin{array}{l}0.77(0.52 \\
1.13)\end{array}$ & $\begin{array}{l}0.89(0.65 \\
1.20)\end{array}$ \\
\hline $\begin{array}{l}\text { Parishes near railway } \\
\text { stations from Oeste line }\end{array}$ & $\begin{array}{c}1.12(0.68 \\
1.75)\end{array}$ & $\begin{array}{l}0.80(0.24 \\
2.01)\end{array}$ & $\begin{array}{c}0.88(0.36 \\
1.83)\end{array}$ & $\begin{array}{l}1.16(0.60 \\
2.06)\end{array}$ & $\begin{array}{c}1.18(0.69, \\
1.89)\end{array}$ \\
\hline $\begin{array}{l}\text { Parishes near railway } \\
\text { stations from } \\
\text { Sado/Fertagus line }\end{array}$ & $\begin{array}{l}0.66(0.50 \\
0.87)\end{array}$ & $\begin{array}{l}0.72(0.43 \\
1.18)\end{array}$ & $\begin{array}{l}0.65(0.42 \\
0.98)\end{array}$ & $\begin{array}{l}0.71(0.50 \\
1.01)\end{array}$ & $\begin{array}{l}0.61(0.45 \\
0.82)\end{array}$ \\
\hline $\begin{array}{l}\text { Parishes near railway } \\
\text { stations from Sintra line }\end{array}$ & $\begin{array}{c}1.42(1.16 \\
1.75)\end{array}$ & $\begin{array}{l}1.41(0.95 \\
2.12)\end{array}$ & $\begin{array}{l}1.44(1.05 \\
2.01)\end{array}$ & $\begin{array}{c}1.27(0.96 \\
1.68)\end{array}$ & $\begin{array}{c}1.41(1.13, \\
1.78)\end{array}$ \\
\hline $\begin{array}{l}\text { Socioeconomic } \\
\text { deprivation (European } \\
\text { Deprivation Index) }\end{array}$ & $\begin{array}{l}1.08(1.05 \\
1.11)\end{array}$ & $\begin{array}{l}0.97(0.92 \\
1.01)\end{array}$ & $\begin{array}{l}1.05(1.01 \\
1.09)\end{array}$ & $\begin{array}{c}1.10(1.07, \\
1.14)\end{array}$ & $\begin{array}{c}1.10(1.07- \\
1.12)\end{array}$ \\
\hline
\end{tabular}

Significant associations are depicted in bold letters.

In the earlier stage of the epidemic, during March, parishes located near the Cascais railway line presented significantly higher infection rates than those located farther away (RR $1.6095 \% \mathrm{Cl} 1.03,2.51)$. In April, when the entire country was under a lockdown, compared to parishes farther from railway stations, parishes near railway stations from Sado/Fertagus line presented significantly lower infection rates (RR 0.65 $95 \% \mathrm{Cl} 0.42,0.98)$, while parishes located near the Sintra line presented significantly higher infection rates (RR $1.4495 \% \mathrm{Cl} 1.05,2.01$ ). During May, when lockdown measures started to ease, no significant associations between railway station proximity and SARS-CoV-2 infection rates were observed. During June/July, as in April, parishes near railway stations from Sado/Fertagus line presented significantly lower infection rates (RR $0.6195 \% \mathrm{Cl} 0.45,0.82$ ), while parishes located near Sintra line presented significantly higher infection rates (RR $1.4195 \% \mathrm{Cl} 1.13,1.78)$.

Regression results also revealed an increasing influence of socioeconomic deprivation on SARS-CoV-2 infection rates. By March, the socioeconomic deprivation index was not significantly associated with parishes' infection rates, while in April and in May, we observed a positive association between socioeconomic deprivation and SARS-CoV-2 infection rates (April: RR 1.05, 95\%Cl 1.01, 1.09; May: 1.10 95\%Cl 1.07, 1.14). 
medRxiv preprint doi: https://doi.org/10.1101/2020.09.18.20195776; this version posted September 18, 2020. The copyright holder for this

\section{DISCUSSION}

Our results showed an inconsistent association between railway station proximity and SARS-CoV-2 infection rates, as both negative and positive associations were observed depending on the railway line and time period. We found that the most at risk areas changed throughout the epidemic and we observed a time-dependent effect of socioeconomic deprivation on area-level SARS-CoV-2 infection rates.

During April, June/July and globally throughout the COVID-19 epidemic period, we observed that parishes near railway stations from the Sintra line had significantly higher SARS-CoV-2 infection rates than parishes far away from railway stations. The Sintra line is one of the most used lines from the Lisbon Metropolitan Area guaranteeing the daily commuting of the population from Sintra and Amadora (the latter is the most densely populated municipality of the country) to the Lisbon municipality (the capital). The Sintra line is currently the busiest in the country (and one of the busiest suburban lines in Europe), carrying several tens of thousands of passengers every day at around 14 trains per hour. During the COVID-19 epidemic, physical distancing was strongly encouraged by health authorities, meaning people should keep about 2 meters or more apart from others. However, trains, such as those from the Sintra line, tend to work at maximum capacity during peak periods, making it difficult to implement such physical distancing. However, simultaneously, parishes near railway stations from Sado/Fertagus lines presented significantly lower SARS-CoV-2 infection rates than those far away from train stations. Sado/Fertagus lines are very busy as well, since they connect the southern parishes of the Lisbon Metropolitan Area located on the left side of the Tagus river estuary to the capital, and carry several tens of thousands of passengers on a daily basis.

Despite this overall pattern, at the earlier stages of the epidemic, the most affected parishes were those crossed by the Cascais line. At this stage, most reported cases were imported and were associated with national individuals coming back from international events (e.g. Milan fashion fairs), Carnival holidays and from snow resorts, many of them in Northern Italy. The Cascais municipality, despite being socioeconomic heterogeneous, is one of the wealthiest municipalities in Portugal (19) and an important tourist destination (20), which explains why it constituted an high-rate area at the earlier stages of the epidemic.

Our findings seem to exclude a direct and consistent association between proximity to railway stations and SARS-CoV-2 infections. However, the lack of association we observed between variables on an aggregate level do not necessarily represent risk at 
medRxiv preprint doi: https://doi.org/10.1101/2020.09.18.20195776; this version posted September 18, 2020. The copyright holder for this preprint (which was not certified by peer review) is the author/funder, who has granted medRxiv a license to display the preprint in perpetuity.

All rights reserved. No reuse allowed without permission.

an individual level. Therefore, we cannot exclude the possibility that some individuals may have acquired the infection inside the train or at railway stations. Hence, reasonable distancing between passengers should be ensured, the use of face mask should be promoted, and disinfection of surfaces (seats, handrails, doors, and ticket machines) should be strengthened to inactivate the virus (21).

Though this was not the main objective of the study, we also observed a consistent increase in the influence of socioeconomic deprivation throughout the epidemic period and after adjusting for vicinity of railway stations. At the initial stage of the epidemic, no differences in infection rates according to socioeconomic deprivation were observed while, from April onwards, we observed roughly $10 \%$ increase in SARS-CoV-2 infection rates per unit increase in the socioeconomic deprivation index. Socioeconomic and ethnic inequalities in COVID-19 distribution and mortality have been reported in the UK (22), Brazil (23) and in the USA (24). Economically disadvantaged people are more likely to live in overcrowded houses, a risk factor for respiratory infections (25); to have unstable working conditions and incomes, being more affected by the economic recession caused by the epidemic (25); to have comorbid conditions, which may hamper the immune system's ability to combat the infection (25) and to have lower access to healthcare (26). Additionally, disadvantaged individuals tend to be employed in occupations that do not provide opportunities to work from home during lockdowns (25). This is a very plausible set of explanations for the increase in the socioeconomic inequalities in SARS-CoV-2 infection rates that we observed from April onwards.

This study has limitations that need to be considered. First, the data and analyses were derived from an ecological approach due to the lack of information of individual use of rail transport, weakening causal inference at the individual level. Ecological designs also limit our capacity to control for confounding, meaning that other factors (for which information was unavailable) rather than proximity to railway stations or socioeconomic deprivation may partially explain our findings (e.g. other modes of transportation, types of activities taking place in each area, population ethnic composition, etc.). Second, our study may be affected by the Modifiable Areal Unit Problem (MAUP) (27), which happens when the number of spatial units (the scale) used to define the same area affects the study conclusions. If the geographical units are large, it is more likely that associations found at the aggregate level will diverge from the same associations found at individual level leading to the so-called ecological fallacy (28). In our study, we used the smallest geographical unit available to minimize this problem. A third issue, is the Uncertain Geographic Context Problem (UGCoP) (29). Case data is available according to the parish of occurrence, but focusing only on occurrence location may introduce uncertainty in research results, because people may spend a considerable 
amount of time in other parishes and may acquire the disease in these locations (e.g. work, transportation, etc.) (30). Finally, case data only includes cases reported to the national surveillance system, which may not be enough to fully comprehend the true magnitude of the COVID-19 pandemic. Although the true number of undetected cases is still to be ascertained, in Europe, the ratio of the total estimated cases to the observed cases was found to around 2.3 (31).

In conclusion, we found no consistent association between proximity to railway stations and SARS-CoV-2 infection rates in the most affected metropolitan area of the country, suggesting other factors, namely neighbourhood socioeconomic deprivation, play a more prominent role in the epidemic dynamics. Nevertheless, our findings do not imply that safety measures in public transportation can be relaxed - proper surface disinfection, physical distancing, and mass mask use should keep being promoted. To guide measures of epidemic control, individual-level studies, namely through the adoption of case-control designs, are recommended to better understand in which locations (e.g. work, school, shopping) there is a higher risk of acquiring the infection.

\section{REFERENCES}

1. Spiteri G, Fielding J, Diercke M, Campese C, Enouf V, Gaymard A, et al. First cases of coronavirus disease 2019 (COVID-19) in the WHO European Region, 24 January to 21 February 2020. Eurosurveillance. 2020;25(9):2000178.

2. Lee VJ, Ho M, Kai CW, Aguilera X, Heymann D, Wilder-Smith A. Epidemic preparedness in urban settings: new challenges and opportunities. The Lancet Infectious diseases. 2020;20(5):527-9.

3. Goscé $L$, Johansson A. Analysing the link between public transport use and airborne transmission: mobility and contagion in the London underground. Environ Health. 2018;17(1):84-.

4. Tirachini A, Cats O. COVID-19 and Public Transportation: Current Assessment, Prospects, and Research Needs. Journal of Public Transportation. 2020;22(1):1.

5. Van Doremalen N, Bushmaker T, Morris DH, Holbrook MG, Gamble A, Williamson BN, et al. Aerosol and surface stability of SARS-CoV-2 as compared with SARS-CoV-1. New England Journal of Medicine. 2020;382(16):1564-7.

6. Wellman GC. Transportation Apartheid: The Role of Transportation Policy in Societal Inequality. Public Works Management \& Policy. 2014;19(4):334-9.

7. Khalatbari-Soltani S, Cumming RC, Delpierre C, Kelly-Irving M. Importance of collecting data on socioeconomic determinants from the early stage of the COVID-19 outbreak onwards. Journal of Epidemiology and Community Health. 2020;74(8):620.

8. Abrams EM, Szefler SJ. COVID-19 and the impact of social determinants of health. Lancet Respir Med. 2020;8(7):659-61.

9. Ramírez IJ, Lee J. COVID-19 Emergence and Social and Health Determinants in Colorado: A Rapid Spatial Analysis. International journal of environmental research and public health. 2020;17(11).

10. Google. Google COVID-19 Community Mobility Reports.

https://www.google.com/covid19/mobility/ Accessed: <27/5/2020> 2020. Available from: https://www.google.com/covid19/mobility/. 
medRxiv preprint doi: https://doi.org/10.1101/2020.09.18.20195776; this version posted September 18, 2020. The copyright holder for this preprint (which was not certified by peer review) is the author/funder, who has granted medRxiv a license to display the preprint in perpetuity.

All rights reserved. No reuse allowed without permission.

11. PortugueseGov. Decreto do Governo que regulamenta o estado de emergência. 2020 [23/6/2020]. Available from:

https://www.portugal.gov.pt/pt/gc22/comunicacao/documento?i=decreto-do-governo-queregulamenta-o-estado-de-emergencia-.

12. Google. Google COVID-19 Community Mobility Reports.

https://www.google.com/covid19/mobility/ Accessed: <20/7/2020>2020. Available from: https://www.google.com/covid19/mobility/.

13. INE. Meio de transporte mais utilizado nos movimentos pendulares (N.) por Local de residência (à data dos Censos 2011) e Principal meio de transporte; Decenal 2011. Available from:

https://www.ine.pt/xportal/xmain?xpid=INE\&xpgid=ine indicadores\&indOcorrCod=0007093\& contexto $=$ bd\&selTab=tab2.

14. Zhang Y, Zhang A, Wang J. Exploring the roles of high-speed train, air and coach services in the spread of COVID-19 in China. Transport Policy. 2020;94:34-42.

15. Zhao S, Zhuang Z, Ran J, Lin J, Yang G, Yang L, et al. The association between domestic train transportation and novel coronavirus (2019-nCoV) outbreak in China from 2019 to 2020: A data-driven correlational report. Travel Medicine and Infectious Disease. 2020;33:101568. 16. Jardim Santos C, Gomes B, Ribeiro Al. Mapping Geographical Patterns and High Rate Areas for Sexually Transmitted Infections in Portugal: A Retrospective Study Based on the National Epidemiological Surveillance System. Sexually transmitted diseases. 2020;47(4):261-8. 17. DGT. Carta Administrativa Oficial de Portugal (CAOP).

http://www.dgterritorio.pt/cartografia e geodesia/cartografia/carta administrativa oficial d e portugal caop/. 2019.

18. Ribeiro Al, Launay L, Guillaume E, Launoy G, Barros H. The Portuguese version of the European Deprivation Index: Development and association with all-cause mortality. PLoS One. 2018;13(12):e0208320-e.

19. INE. Poder de compra per capita por Localização geográfica (NUTS - 2013); Bienal - INE, Estudo sobre o poder de compra concelhio 2017. Available from:

https://www.ine.pt/xportal/xmain?xpid=INE\&xpgid=ine indicadores\&indOcorrCod=0008614\& contexto $=\mathrm{bd} \&$ selTab=tab2.

20. CMC. Mergulhe no mar de Cascais. Praias [Dive into Cascais's sea. Beaches] 2020. Available from: $\mathrm{https}$ ://ambiente.cascais.pt/pt/espacos/praias.

21. Musselwhite C, Avineri E, Susilo Y. Editorial JTH 16 -The Coronavirus Disease COVID-19 and implications for transport and health. J Transp Health. 2020;16:100853-.

22. Wright L, Steptoe A, Fancourt D. Are we all in this together? Longitudinal assessment of cumulative adversities by socioeconomic position in the first 3 weeks of lockdown in the UK. Journal of Epidemiology and Community Health. 2020:jech-2020-214475.

23. Baqui P, Bica I, Marra V, Ercole A, van der Schaar M. Ethnic and regional variations in hospital mortality from COVID-19 in Brazil: a cross-sectional observational study. The Lancet Global Health. 2020;8(8):e1018-e26.

24. Chin T, Kahn R, Li R, Chen JT, Krieger N, Buckee CO, et al. U.S. county-level characteristics to inform equitable COVID-19 response. medRxiv. 2020:2020.04.08.20058248.

25. Patel JA, Nielsen FBH, Badiani AA, Assi S, Unadkat VA, Patel B, et al. Poverty, inequality and COVID-19: the forgotten vulnerable. Public Health. 2020;183:110-1.

26. Ribeiro Al, Krainski ET, Carvalho MS, de Fátima de Pina M. The influence of socioeconomic deprivation, access to healthcare and physical environment on old-age survival in Portugal. Geospatial Health. 2017;12(2).

27. Openshaw S, Taylor PJ, Wrigley N. Statistical applications in the spatial sciences. London: Edited by N Wrigley Pion. 1979:127-44.

28. Aikins E, Ribeiro Al. Elements of Health and Medical Geography: Kendall Hunt; 2020. 29. Kwan M-P. The uncertain geographic context problem. Annals of the Association of American Geographers. 2012;102(5):958-68. 
medRxiv preprint doi: https://doi.org/10.1101/2020.09.18.20195776; this version posted September 18, 2020. The copyright holder for this preprint (which was not certified by peer review) is the author/funder, who has granted medRxiv a license to display the preprint in perpetuity. All rights reserved. No reuse allowed without permission.

30. Ribeiro Al. Public health: why study neighborhoods? Porto Biomed J. 2018;3(1):e16-e. 31. Böhning D, Rocchetti I, Maruotti A, Holling H. Estimating the undetected infections in the Covid-19 outbreak by harnessing capture-recapture methods. International Journal of Infectious Diseases. 2020. 